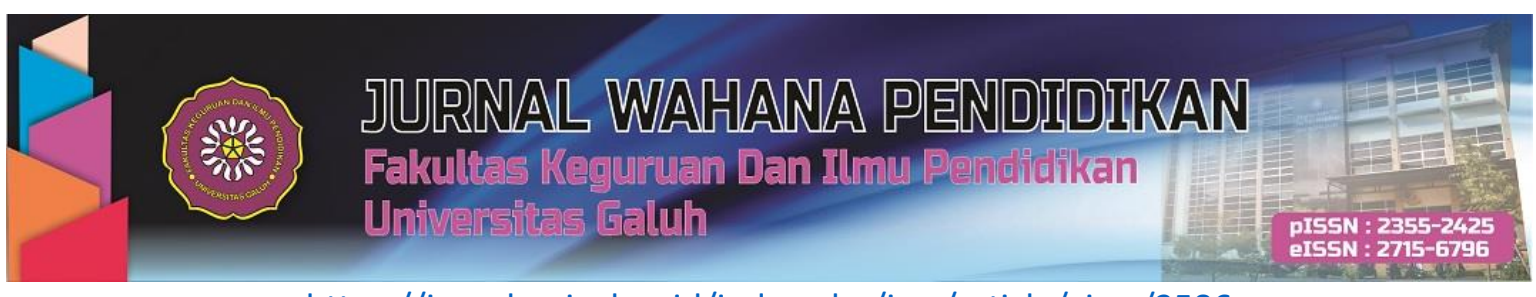

https://jurnal.unigal.ac.id/index.php/iwp/article/view/3586

\title{
EKRANISASI NOVEL DUA GARIS BIRU KARYA LUCIA PRIANDARINI KE BENTUK FILM DUA GARIS BIRU KARYA GINA S. NOER DAN IMPLIKASINYA TERHADAP PEMBELAJARAN SASTRA DI SMA
}

\author{
Syifa Aniskurli' ${ }^{1}$, Sri Mulyati ${ }^{1}$, Syamsul Anwar ${ }^{1}$ \\ ${ }^{1}$ Proram Studi Pendidikan Bahasa Sastra Indonesia, Universitas Pancasakti Tegal \\ Email: syifaanis98@gmail.com, srimulyati03@gmail.com, syamsulanwar590@.gmail.com.
}

\begin{abstract}
The purpose of this study was to examine the forms of ekranisasi novel Dua Garis Biru by Lucia Priandarini to the Dua Garis Biru movie by Gina S. Noer and the implications of learning in High School. This research only presents forms of plot and character ekranisasi in the novel to the film. This study uses a qualitative method. Descriptive method for describing the forms of ekranisasi in novels and films Dua Garis Biru. The data source used is the novel Dua Garis Biru by Lucia Priandarini and the film Dua Garis Biru by Gina S. Noer. The data are in the form of excerpts from the novel Dua Garis Biru by Lucia Priandarini and film Dua Garis Biru by Gina S. Noer. Data colletion uses reading, watching, and note techniques. Analysis of the results using descriptive analysis techniques with three steps, namely describing, analyzing data, and completing results. This research produces, updates, and changes the forms of ekranisasi from the novel to the film Dua Garis Biru. This research can be applied to Indonesia language learning specifically Indonesia Specialization in class XII second semester (even) with basic competence of 3,9 Analyzing novel content and linguistics, and 4.9 Designing novels or novels by paying attention to the contents and linguistics both oral and written.
\end{abstract}

Keywords: Ekranisasi, Implications of learning, Movies and Novels Dua Garis Biru

\section{ABSTRAK}

Tujuan penelitian ini adalah untuk meneliti bentuk-bentuk ekranisasi novel Dua Garis Biru Karya Lucia Priandarini ke bentuk film Dua Garis Biru Karya Gina S. Noer dan Implikasi Pembelajarannya di SMA. Penelitian ini hanya memaparkan bentuk-bentuk ekranisasi alur dan tokoh pada novel ke film. Pendekatan kualitatif dengan metode deskriptif digunakan dalam penelitian ini. Metode deskriptif untuk mendeskripsikan bentuk-bentuk ekranisasi dalam novel dan film Dua Garis Biru. Sumber data yang digunakan adalah novel Dua Garis Biru Karya Lucia Priandarini dan Film Dua Garis Biru Karya Gina S. Noer. Wujud data berupa kutipan pada novel Dua Garis Biru Karya Lucia Priandarini dan Film Dua Garis Biru Karya Gina S. Noer. Pengumpulan data menggunakan teknik baca, tonton dan catat. Penyajian hasil analisis menggunakan teknik deskriptif analisis dengan tiga langkah, yaitu mendeskripsikan, menganalisis data, dan menyimpulkan hasilnya. Penelitian ini menghasilkan pengurangan, penambahan, dan perubahan bervariasi yang merupakan bentuk-bentuk ekranisasi dari novel ke film Dua Garis Biru. Penelitian ini dapat di implikasikan pada pembelajaran Bahasa Indonesia khususnya Bahasa Indonesia Peminatan kelas XII semester dua (genap) dengan kompetensi dasar yaitu 3.9 Menganalisis isi dan kebahasaan novel, dan 4.9 Merancang novel atau novelet dengan memerhatian isi dan kebahasaan baik secara lisan maupun tulis.

Kata kunci: Ekranisasi, Novel dan Film Dua Garis Biru, Implikasi Pembelajaran

Cara sitasi:

Aniskurli, A., Mulyati, S., \& Anwar, S. (2020). Ekranisasi Novel Dua Garis Biru Karya LUCIA Priandarini ke Bentuk Film Dua Garis Biru Karya Gina S. Noer dan Implikasinya Terhadap Pembelajaran Sastra di SMA. Jurnal Wahana

Pendidikan, 7 (2), 139-150.

Sejarah Artikel:

Dikirim 21 Februari 2020, Direvisi 2 Juli 2020, Diterima 12 Juli 2020 


\section{PENDAHULUAN}

Sastra merupakan hasil cipta karya manusia yang indah dan estetis sehingga dapat menarik pembaca untuk menikmatinya. Selain itu, sastra adalah hasil cipta karya manusia yang dituangkan melalui ekspresi berupa tulisan dan bahasa sebagai perantaranya. Menurut Sumardjo dan Saini (Rokhmansyah 2014:2) sastra pada dasarnya ungkapan pribadi manusia yang mempunyai daya tarik dengan alat bahasa meliputi pengalaman pemikiran, perasaan, ide.

Ekraniasasi berasal dari bahasa Perancis, yakni ecran yang berarti layar. Eneste (1991: 60) menjelaskan perpindahan dari novel ke film mengakibatkan terjadinya proses pelayarputihan. Pemindahan dari novel ke layar putih mau tidak mau akan terjadi berbagai perubahan. Oleh karena itu, dalam proses ekranisasi terdapat berbagai perubahan baik berupa pengembangan, penciutan, maupun perubahan dengan sejumlah variasi karena dipengaruhi beberapa faktor, antara lain media yang digunakan, peminat penonton.

Eneste (1991: 61) menjelaskan beberapa proses terjadinya perubahan dalam ekranisasi yakni sebagai berikut: 1) Pengurangan: langkah yang harus ditempuh dalam proses transformasi karya sastra salah satunya adalah pengurangan dari novel ke film. Pengurangan adalah pemotongan karya sastra dalam proses transformasi unsur cerita sehingga terjadi perubahan. Eneste (1991: 62) mengungkapkan bahwa pada dasarnya pengurangan dalam karya sastra terjadi pada alur, tokoh, latar, dan suasana. Dengan adanya proses pengurangan atau pemotongan tidak semua apa yang ada di dalam novel akan ditemukan pula di dalam film. 2) Penambahan: perubahan karya sastra dalam proses transformasi dari novel ke bentuk film. Sama halnya dengan pengurangan, proses ini juga bisa terjadi pada ranah cerita, alur, penokohan, latar, maupun suasana. Penambahan yang terjadi dalam proses ekranisasi ini tentunya memiliki alasan. Eneste (1991: 64) menyatakan bahwa penambahan dalam film sangat penting untuk seorang sutradara karena untuk menunjang dari segi filmis. 3) Perubahan Bervariasi: proses transformasi yang memungkinkan terjadinya dari karya sastra ke bentuk film. Eneste (1991: 65) megemukakan dalam ekranisasi kemungkinan dapat terjadi variasi antara novel dan film. Pada dasarnya dalam transformasi dapat dipengaruhi oleh beberapa faktor yaitu, media yang digunakan, persoalan penonton, dan durasi waktu pemutaran. Variasi juga dapat terjadi dalam ranah ide cerita, gaya penceritaan, dan sebagainya. Eneste (1991:67) menyatakan bahwa dalam mengekranisasi film perlu membuat variasi dalam film, sehingga film yang didasari atas novel itu lebih terkesan dan tidak seasli dari novelnya.

Ekranisasi merupakan perubahan hasil kerja yang meliputi dari bentuk, sifat, dan fungsinya. Hal tersebut dikarenakan adanya keterbatasan dalam media film baik berupa tenaga, dana, waktu, maupun durasi. Bagus tidaknya sebuah film, bergantung pada kekompakan tim diantaranya: produser, penulis, sutradara, juru kamera, penata artistik, perekam suara, para pemain Eneste (1991: 60). Ekranisasi berkaitan dengan proses perubahan wahana dari kata-kata menjadi wahana gambar. Oleh karena itu, perubahan berupa pengembangan dan penciutan tidak bisa terhindar dan harus disesuaikan dari durasi film Damono (2018: 117). Durasi dalam film sangatlah terbatas yaitu sekitar 90 hingga 130-an menit, karena tuntutan dari pihak komersial (layar bioskop). Jadi, yang dimaksud dengan ekranisasi adalah suatu proses pemindahan atau pengadaptasian dari karya sastra berbentuk novel ke bentuk film.

Novel adalah karya sastra yang mengandung rangkaian cerita kehidupan dari setiap tokoh dengan menonjolkan karakter setiap tokoh. Pada dasarnya novel dikatakan sebuah karya fiksi karena berisi tentang model kehidupan yang diidealkan, dunia imajinatif, yang dibangun melalui berbagai unsur instrinsiknya yang bersifat imajinatif Nurgiyantoro (2015: 5). Novel merupakan karya fiksi yang mengemukakan suatu gagasan tentang kemanusiaan yang lebih mendalam dan disajikan dengan halus Nurgiyantoro (2002: 9). Prosa fiksi sendiri merupakan kisah atau cerita yang di perankan oleh pelaku tertentu, tahapan dan rangkaian cerita hasil imajinasi dari pengarangnya yang bertolak untuk menjalin suatu cerita Aminuddin (2013: 66). 
Dalam novel ada 7 unsur instrinsik yakni, Tema, adalah ide pikiran yang menjalin suatu struktur cerita. Nurgiyantoro (2015: 114) mengemukakan bahwa tema adalah makna yang terkandung dalam sebuah cerita. Menurut Aminuddin (2013:91) tema adalah dasar ide cerita yang dipaparkan oleh pengarang dalam sebuah karya fiksi. Tokoh/ penokohan adalah pelaku cerita yang memiliki watak atau karakter yang berbeda. Menurut Aminuddin (2009: 79) tokoh adalah pemeran yang terdapat dalam peristiwa cerita fiksi dan menjalin suatu cerita. Jones (Nurgiyantoro 2015: 247) penokohan merupakan gambaran tentang seorang tokoh yang ditampilkan dalam sebuah cerita. Dengan demikian, character berarti 'pelaku cerita' dapat pula 'perwatakan'. Sebagaimana dikemukakan oleh Abrams (Nurgiyantoro 2015: 247) tokoh cerita (character) adalah karya naratif yang di dalamnya menafsirkan serta menampilkan seorang tokoh melalui pembaca yang memiliki kualitas moral dan kecenderungan ekspresi yang di ucapan dan dilakukan dalam tindakan. Alur/ plot, Aminuddin (2013:83), alur adalah rangkaian cerita yang terjadi di dalam peristiwa dan menjadi cerita yang dibawakan oleh para pemain dalam cerita. Menurut Stanton (Nurgiyantoro, 2015: 167) mengemukakan plot adalah cerita yang berisi urutan kejadian, dan disebabkan secara sebab akibat. Latar/ setting, adalah latar sebuah peristiwa berupa tempat, waktu, yang berkaitan dengan gejala dan kegiatan jiwa Aminuddin (2013: 67). Latar atau setting yang disebut juga sebagai dasar berupa tempat, waktu, dan lingkungan sosial tempat terjadinya peristiwa yang terdapat di dalam cerita Abrams (Nurgiyantoro, 2015: 302). Sudut pandang, Pada dasarnya sudut pandang dapat dibedakan menjadi dua macam (Ratna, 2015: 319) yaitu: (a) Sudut pandang orang pertama yang berkaitan erat dengan pencerita dan penulis sehingga seolah-olah ikut mengalami secara langsung dalam ceritanya. (b) Sudut pandang orang ketiga merupakan pencerita tidak berhak memihak terhadap tokoh dan kejadian karena berada di luar cerita. Gaya bahasa, merupakan bahasa yang digunakan dalam sebuah peristiwa. Amanat merupakan pesan moral yang terkandung di dalam cerita yang ingin disampaikan dari seorang pengarang kepada pembacanya. Amanat pada dasarnya menjadi pendirian, sikap, atau pendapat seorang pengarang mengenai inti dari persoalan, dengan kata lain amanat adalah pengarang atas persoalan yang dibuatnya Eneste (1991: 57). Kemudian unsur ekstrinsik meliputi unsur biografi, unsur psikologi, keadaan lingkungan, dan pandangan hidup pengarang. Teks karya sastra menggunakan bahasa dan kata-kata, sementara dalam film menggunakan bentuk visual (gambar).

Film secara harfiah yakni sinema, dijelaskan yakni cinemathographic yang berasal dari kata cinema dan tho/ "phytos" yakni cahaya serta graphic adalah tulisan/ gambar/ citra, bisa dikatakan film tersebut berarti melukiskan suatu gerak dengan cahaya (Kartika, 2016). Definisi lain dari film yakni, film merupakan hasil cipta karya seni yang memiliki kelengkapan dari beberapa unsur seni untuk melengkapi kebutuhan yang sifatnya spiritual. Film melakukan komunikasi verbal melalui dialog (seperti drama), film mempergunakan irama yang kompleks dan halus (seperti musik), film berkomunikasi melalui citra, metafora, dan lambang-lambang (seperti puisi), film memusatkan diri pada gambar bergerak (seperti pantomim) yang memiliki ritmis tertentu (seperti tari), dan akhirnya film memiliki kesanggupan unutk memainkan waktu dan ruang, mengembangkan dan mempersingkatnya, memajukan atau memundurkannya secara bebas dalam batas-batas wilayah yang cukup lapang.

Film dianggap sebagai media komunikasi yang ampuh terhadap massa, karena sifatnya audio visual atau gambar dan suara yang hidup. Jadi, film merupakan wujud gerak dengan cahaya. Bluestone (Eneste, 1991: 18) pada dasarnya film merupakan gabungan dari berbagai ragam jenis kesenian. Baik dan tidaknya sebuah film sangat bergantung pada kekompakan tim dalam berkerja. Berbeda dari novel, film berkomunikasi tidak melalui lambang-lambang abstrak yang dicetak di atas halaman kertas sehingga memerlukan suatu penerjemahan oleh otak ke pelukisan visual dan suara, tapi langsung melalui gambar-gambar visual dan suara nyata Boggs (Asrul Sani, 1992: 4).

Beberapa film Indonesia yang diadaptasi dari novel antaralain: Surga yang Tak Dirindukan (transformasi novel karya Asma Nadia ke film oleh Kuntz Agus), Bidadari-Bidadari Surga (transformasi novel Bidadari-Bidadari Surga karya Tere Liye ke film oleh Soni Gaokasak), dan lain 
sebagainya. Eneste (1991: 60) menyatakan bahwa film merupakan hasil kerja tim secara kompak. Dari penjelasan tersebut, menjadi alasan penulis dalam melakukan penelitian pada novel Dua Garis Biru karya Lucia Priandarini dan film Dua Garis Biru karya Gina S. Noer untuk menyampaikan unsur instrinsik yang terdapat dalam novel tersebut, yang sebelumnya belum pernah dianalisis secara struktural dan juga perbandingan di antara keduanya.

Ekranisasi dalam penelitian ini dapat menjadi acuan dalam pembelajaran Bahasa Indonesia khususnya pada materi ekranisasi novel. Hal itu karena banyak siswa dan guru yang belum mengerti bahwa novel bisa di adaptasi ke dalam film melalui proses transformasi. Adanya penelitian ini bisa menambah pengetahuan guru dan siswa bahwa di dalam materi novel terdapat pengadaptasian terhadap novel ke dalam bentuk film.

Fenomena di atas, dapat juga dijumpai novel yang bercerita tentang novel Dua Garis Biru. Novel Dua Garis Biru tersebut yang menjadi alasan dalam penelitian ini. Proses di atas muncul pada alur cerita film Dua Garis Biru yang diangkat dari sebuah novel dengan judul sama karya Lucia Priandarini. Setelah novel tersebut diangkat ke layar lebar, fakta menunjukkan bahwa untuk menguraikan alur cerita yang panjang tersebut, durasi film Dua Garis Biru hanya menghabiskan waktu 113 menit.

Berdasarkan uraian yang telah dijelaskan pada latar belakang di atas, rumusan masalah dalam penelitian ini sebagai berikut. (1) Bagaimana bentuk ekranisasi (alur dan penokohan) antara novel Dua Garis Biru karya Lucia Priandarini ke dalam film Dua Garis Biru karya Gina S. Noer? (2) Bagaimana Implikasinya terhadap pembelajaran sastra di SMA? Sesuai dengan rumusan masalah yang ada, tujuan penelitiannya dirumuskan sebagai berikut (1) Mendeskripsikan bentuk ekranisasi (alur dan penokohan) antara novel Dua Garis Biru karya Lucia Priandarini ke dalam film Dua Garis Biru karya Gina S. Noer. 2) Mendeskripsikan Implikasinya terhadap pembelajaran sastra Indonesia. Manfaat penelitian ini diharapkan dapat memperbanyak pandangan dan pemahaman yang mutakhir bagi kemajuan ilmu utamanya sastra Indonesia serta dapat menumbuhkan penghargaan berkenaan dengan analisis karya sastra yang berhubungan dengan ekranisasi novel dan film.

\section{METODE PENELITIAN}

Pendekaatan Penelitian ini menggunakan pendekatan kualitatif. Pendekatan kualitatif adalah metode penelitian yang bertumpu pada kelemahan kondisi objek yang alamiah yakni peneliti adalah sebagai instrumen kunci atau peneliti itu sendiri. Teknik pengumpulan data dilakukan secara (gabungan), analisis data bersifat induktif/ kualitatif, dan hasil penelitian kualitatif lebih menegaskan makna dari pada yang sesungguhnya Sugiyono (2015: 9). Ratna (2015: 46) mengatakan metode kualitatif menyajikan data secara deskriptif yang memanfaatkan melalui penafsiran. Oleh karena iu, dapat disimpulkan metode kualitatif tidak menggunakan angka-angka dalam menganalisis data, tetapi menggunakan kata-kata untuk mendeskripsikan. Jadi simpulan dari uraian di atas peneliti kualitatif dituntut mampu mengorganisasikan dan menemukan semua teori yang diperoleh kemudian dibaca sesuai dengan subjek yang akan diteliti. Sumber data yang memuat data pokok yakni data yang didapat secara langsung disebut dengan sumber data primer yang berasal dari data kepustakaan. Teks novel Dua Garis Biru karya Lucia Priandarini dan film Dua Garis Biru karya Gina S. Noer yang menjadi subjek material novel cetakan kedua yang dikeluarkan oleh penerbit PT Gramedia Pustaka Utama pada bulan Agustus 2019 dengan tebal 206 halaman menjadi sumber data primer dalam penelitian ini. Penelitian ini termasuk kualitatif. Oleh karena itu wujud datanya berupa kata, kalimat, dan wacana yang menunjukkan ekranisasi novel ke film Dua Garis Biru.

Teknik Pengumpulan Data dalam novel, penulis membaca secara menyeluruh dan berulang-ulang pada Novel Dua Garis Biru. Selain membaca novel, penulis juga melakukan pengamatan terhadap film Dua Garis Biru untuk dapat menganalisis lebih lanjut mengenai alur dan penokohan. Selanjutnya teknik membaca, menonton, dan mencatat, yaitu penulis membaca novel terlebih dahulu kemudian menonton film selanjutnya mencatat data-data yang ditemukan di dalam Novel dan Film mengenai unsur Instrinsik. Data itu kemudian dianalisis dengan menggunakan teknik 
komparatif-induktif dan proses ekranisasi. Melakukan penafsiran antara data yang satu dengan data yang lain. Kemudian mendeskripsikannya ke dalam persamaan dan perbedaan melalui unsur instrinsik. Maksud peneliti mulai dari pembacaan dan pemahaman novel Dua Garis Biru secara umum dan pengamatan terhadap film Dua Garis Biru. Kemudian mengidentifikasi perubahan unsur instrinsik yang terdapat diantara dua karya tersebut.

\section{HASIL DAN PEMBAHASAN}

Ekranisasi Novel Dua Garis Biru Karya Lucia Priandarini ke bentuk Film Dua Garis Biru Karya Gina S. Noer dan Implikasinya terhadap Pembelajaran Sastra di SMA adalah objek penelitian. Penulis menganalisis dan mendeskripsikan bentuk ekranisasi (alur dan penokohan) antara novel Dua Garis Biru karya Lucia Priandarini ke dalam film Dua Garis Biru karya Gina S. Noer.

\section{Bentuk Ekranisasi Alur dari Novel Dua Garis Biru ke bentuk Film Dua Garis Biru}

Ada tiga bentuk ekranisasi alur novel Dua Garis Biru ke bentuk film Dua Garis Biru, yaitu pengurangan penambahan, dan perubahan bervariasi.

\section{Pengurangan}

a. Bagian awal novel dan film

Dalam novel Dua Garis Biru, bagian awal cerita pada bab "Mau Jadi Apa" menggambarkan masa depan Bima sebagai murid yang selalu mendapatkan nilai ulangan jelek di kelasnya. (Data 1)

Kini Bima menatap kertas ulangan fisikanya dengan ngeri. Kertas itu penuh coretan dan lingkaran merah, seperti biasa ia memang cuma menulis rumus dan hanya satu soal saja yang kebetulan ia jawab dengan benar. (Dua Garis Biru, 2019: 9).

Kutipan di atas menggambarkan tokoh Bima yang selalu mendapatkan nilai jelek karena kemalasannya dan tidak mementingkan untuk masa depan.

b. Seprainya kusut, sama kusutnya dengan perasaan

Dalam novel Dua Garis Biru, pada bab "Tidak Apa-Apa" Dara kepergok oleh Ibunya karena tidak biasanya Dara ganti seprai pada malam hari.

(Data 2)

Dengan langkah berat, Dara mendorong kursi ke pintu lemari, meraih satu set seprai dan bed cover dari rak teratas.

"Dara?" Ibu Dara mengintip ke kamar putri sulungnya dan bertanya-tanya.

"Dara!" ngapain malam-malam ganti seprai?" dahi lbu Dara bekerut.

"Mm...tadi Dara tidur siang mens nembus". Dara terdiam lalu menengok jam kalender di meja belajar Dara.

"Bukannya baru seminggu lalu kamu mens?"

"Ngga ngerti juga ma". Dara menjawab singkat. (Dua Garis Biru, 2019:24)

Kutipan di atas memaparkan seorang lbu curiga dengan hal yang tidak biasa dilakukan oleh anaknya di malam hari.

Sementara di dalam film Dua Garis Biru tidak menceritakan peristiwa tersebut. Tetapi langsung menceritakan suasana di kelas keesokan harinya ketika Dara dan Bima bersama di dalam kamarnya. Hal inilah yang membuat alur pada novel berbeda dengan alur pada film. Di dalam novel terdapat alur campuran sedangkan di dalam film menggunakan alur maju.

c. Bima resah dengan keadaan yang sedang di alaminya

Dalam novel Dua Garis Biru terdapat bab "Bantuan Ondel-Ondel" menceritakan tentang Bima yang tidak bisa tidur karena kebingungan mencari uang untuk keperluan periksa kandungan Dara. Perintah Ibunya mengantarkan pesanan gado-gado dan ada uang kembalian ke Bu Saodah sekilas menjadi hasutan untuk Bima mencuri uang di laci gado-gado milik Ibunya.

(Data 3)

Lambaian tangan Ibunya menyuruh Bima untuk mengantarkan pesanan gado-gado dengan kembalian dua puluh ribu ke rumah Ibu Saodah. Ibunya langsung masuk ke 
rumah, meninggalkan laci penuh uang kerta dan receh di hadapan Bima yang lupa di tutup.

"Ambil saja!" seperti mendengar hasutan.

Sementara hatinya berkata "jangan!" seketika Bima mendengar suara azan asar. Bima tersentak langsung menutup laci rapat-rapat lalu bergegas ke rumah Bu Saodah (Dua Garis Biru, 2019:63)

Kutipan di atas menunjukan Bima yang sedang kebingungan mencari uang untuk biaya kandungan Dara dan terhasut ketika melihat uang bercecer di dalam dompet yang di letakkan di laci gado-gado milik Ibunya.

Sementara itu, di dalam film Dua Garis Biru tidak menceritakan Bima yang kebingungan mencari uang. Akan tetapi, dalam film Dua Garis Biru langsung adegan Bima sedang duduk di poskamling bersama Emir dan Danang. Tidak lama kemudian suara musik dari ondel-ondel mendekat dan Bima tanpa basa basi langsung meminta tolong kepada Pong (ondel-ondel) karena Bima sudah terbiasa ketika sedang membutuhkan uang cuma Pong yang bisa membantu.

\section{d. Liburan akhir tahun}

Dalam novel Dua Garis Biru terdapat bab "Rencana Untuk Stroberi" yang menceritakan Dara meratapi keadaan yang sedang di alaminya. Bingung dengan kejadian yang sedang di laluinya karena takut dengan orang tuanya yang belum mengetahui yang sedang di rasakan oleh Dara. (Data 4)

...Ibu dan adiknya sedang mengobrol tentang liburan akhir tahun. Dara seketika langsung mengatur napas karena pada akhir tahun kandungannya akan berumur lima bulan (Dua Garis Biru, 2019:57)

Kutipan di atas menunjukkan Dara yang kebingungan akan rencana pada akhir tahun nanti karena usia kandungannya sudah mulai membesar.

Sementara itu, di dalam film Dua Garis Biru tidak di tampilkan cerita tersebut. Tetapi langsung menceritakan Dara yang sedang tiduran di kamarnya memegang dan memerhatikan stroberi yang ada di tangannya, kemudian menarik kaus sesekali mengusap perutnya yang masih tampak normal.

e. Firasat yang tidak enak dan mulai merasakan kejanggalan pada anaknya

Dalam novel Dua Garis Biru, pada bab "Melumat Stroberi" Bima sudah mempersiapkan semuanya untuk pergi mencari tempat aborsi bersama Dara. Sebelumnya Bima sudah mencari tahu di mesin pencari tentang aborsi namun hasil pencariannya tidak ada bagus-bagusnya yang paling menggentarkan adalah tiga puluh persen aborsi ilegal, terutama pada perempuan muda, berujung kematian.

(Data 5)

Bima bergidik setelah melihat orang tua Dara. Langkahnya terus menuju ke halaman rumah Dara mencium tangan kedua orang tua Dara bergantian.

"Berangkat duluan om, tante. Assalamualaikum"

"Waalaikumsalam," jawab Ayah dan Ibu Dara.

"Kamu kenapa sih yang?" Ayah Dara bingung.

"Perasaanku ngga enak" saut Ibu Dara.

"Tenang aja. Dara kan kalau ada apa-apa selalu ngomong".

Ibu Dara termangu yakin (Dua Garis Biru, 2019:69)

Kutipan percakapan di atas menunjukkan firasat Ibu Dara yang sudah mulai merasakan kejanggalan karena melihat tingkah laku Dara yang mulai mencurigakan.

Sementara itu, di dalam film Dua Garis Biru tidak di menceritakan adegan percakapan tersebut. Akan tetapi, dalam film Dua Garis Biru setelah Bima meminjam uang di Pong (ondel-ondel) langsung menceritakan Bima dan Dara sudah sampai di sudut gang yang mereka tuju.

(Data 6) 
Dalam novel Dua Garis Biru di ceritakan Bima yang mendapat nilai ujian akhir semester matematika dan merasa frustasi dengan masalah yang sedang di hadapi.

Tidak ada masalah saja ia cuma bisa mengisi setengah soal UAS. Kini masalah besarnya semakin membuat pikirannya berkelok dan berujung buntu.

"Bima pacaran terus sih," begitu celetuk satu-dua orang. Bima cuma tersenyum.

"Bisa tadi?" Bima bertanya pada Dara, basa-basi.

Dara mengangguk kecil "Lumayan" (Dua Garis Biru, 2019:79)

Kutipan di atas menunjukkan Bima yang menutupi kemurungannya dan berusaha biasa saja di depan Dara padahal perasaan Bima sendiri sangat sulit dikendalikan.

Sementara itu, di dalam film Dua Garis Biru tidak menceritakan adegan Bima di ruang kelas dan mendapat nilai ujian akhir semester. Akan tetapi sebelum menceritakan adegan Bima meminta ijin untuk kuliah kepada kedua orang tuanya. Bima membelikan rok sekolah untuk Dara dan di antarkannnya ke rumah. Hal inilah yang membuat alur pada novel berbeda dengan alur yang ada pada film. Novel menggunakan alur campuran sedangkan film menggunakan alur maju.

f. Film Dua Garis Biru tidak menceritakan Dara menawarkan bantuan ke Ibu Bima Dalam film Dua Garis Biru cuma menceritakan adegan Dara ketika sudah di ambang pintu kamar mandi dan menolak air rebusan yang di buatkan oleh Bima untuk Dara.

(Data 7)

"Saya bantu tante" Dara merasa tidak enak hanya menumpang makan dan tidur.

"Eh nggak, nggak usah"

"Tante beneran, saya bisa nyuci piring kok". Dara mencoba mengambil piring yang sedang di sabuni Ibu Bima.

Tapi piring malah terlontar dan pecah.

"Maaf ya tante"

"Sudah kamu mandi aja" (Dua Garis Biru, 2019:107)

Kutipan di atas menunjukkan Dara yang ingin membantu lbu Bima karena merasa canggung hanya menumpang makan dan tidur tidak pernah membantu Ibu Bima di rumahnya.

Sementara itu, di dalam film Dua Garis Biru tidak menceritakan adegan Dara yang menawarkan bantuan kepada Ibu Bima. Akan tetapi, dari adegan Bima dan Dara di kamar Bima langsung menuju adegan Dara yang sedang di periksa oleh Dokter kandungan.

\section{Penambahan}

a. Bima mendapat kabar dari Dara perihal rencana orang tuanya.

Penambahan alur cerita selanjutnya yaitu pada film Dua Garis Biru di ceritakan pada film anak yang di kandungnya akan di adopsi oleh Om dan Tantenya kata Puput. Dara langsung menghampiri orang tuanya yang sedang duduk santai di ruang makan, seketika Dara langsung menelpon Bima memberitahunya. Dalam novel tidak di ceritakan demikian tetapi novel menceritakan semua percakapan di telponnya, tetapi di dalam film tidak di tampilkan jelas percakapan yang di bicarakan oleh Dara kepada Bima.

(Data 8)

"Kamu kok diam saja sih?” Dara jadi kesal karena Bima terdengar tidak bereaksi.

"Aku..lagi..mikir.." Bima tidak berbohong. la memang sedang memikirkan sebuah kemungkinan yang selama ini terlalu takut ia ungkapkan.

"Mikir apa?" tukas Dara ketus.

"Gimana kalau kita..." Lidah Bima kelu

"Apa sih?" Dara makin gusar.

"Gimana kalau kita...nikah?" (Dua Garis Biru, 2019:118)

Berdasarkan kutipan di atas, pada novel Dua Garis Biru menceritakan semua keputusan yang sudah di sepakati oleh kedua orang tua Dara. Bima langsung tidak bersuara ketika Dara bercerita. Singkat cerita akhirnya Bima menemukan jalan keluar dengan mengajak Dara menikah agar orang tuanya membatalkan rencana yang sudah disepakati dengan Om dan Tante Dara. 


\section{b. Setelah akad}

Penambahan berikutnya yaitu diceritakan Dara dan Bima merasa bahagia sudah resmi menjadi suami istri, tetapi dalam kamar mereka masih membahas soal pelajaran dan nilai Bima di sekolahnya.

(Data 9)

...Bima sedang mengerjakan PR metematika. Dara menemani. Di sisi mereka ada setoples kacang almond, cemilan Dara.

"Masa kamu kaya gini nggak bisa sih?" Dara gemas melihat Bima lama sekali menghitung sebuah soal integral.

"Aku kan nggak sepintar kamu," kata Bima sambil meraup sejumput kacang.

"Tapi aku bersyukur sih." Bima mengunyah.

"Aku kemaren baca-baca di internet katanya kecerdasan bayi menurun dari ibunya. Untung tidak nurun dari bapaknya," Bima berceloteh (Dua Garis Biru, 2019:133)

Berdasarkan kutipan di atas, menunjukkan dalam novel Dua Garis Biru diceritakan Bima dan Dara masih terbawa seperti anak sekolah umumnya meskipun Dara sudah tidak sekolah tetapi semangatnya luar biasa. Sementara di dalam film Dua Garis Biru tidak menceritakan adegan Bima dan Dara membahas tentang pelajaran yang ada di sekolahnya tetapi langsung sesudah akad nikah Bima dan Dara sedang berada di kamar Dara. Bima menirukan gaya yang dilakukan oleh Dara.

c. Menjelang Persalinan

Dalam novel Dua Garis Biru, adegan Bima yang sedang mengazani anaknya. Tidak lama kemudian Bima disuruh untuk menandatangani formulir setelah Dara melahirkan karena terjadi komplikasi pendaharan dan untuk opsi terakhir adalah menghentikan pendarahan pengangkatan rahim. Tetapi di dalam film Dua Garis Biru, tidak ada adegan ketika Bima sedang mengazani anaknya.

(Data 10)

Bima mendekatkan wajahnya ke telinga Adam. Takjub. Sambil mempererat gendongan, ia perlahan membisikkan azan ke telinga Adam (Dua Garis Biru, 2019:199)

Berdasarkan kutipan di atas, memaparkan bahwa Bima sadar selaku sudah menjadi ayah dari anaknya yang baru lahir itu.

\section{Perubahan bervariasi}

a. Perbedaan Cerita Awal dalam Novel Dua Garis Biru dan Film Dua Garis Biru

Ketika masuk pada adegan utama, antara novel dan film memiliki perbedaan yang sangat jelas, novel Dua Garis Biru menggunakan alur maju-mundur (campuran), sedangkan dalam film Dua Garis Biru menggunakan alur maju. Sedangkan dalam film adegan diawali dengan credit title yaitu adegan hasil modifikasi yang dilakukan pada alur film, karena tidak ditemukannya adegan ini pada novel yang berfungsi sebagai hipogram atau unsur ceritanya. Kemudian menceritakan cerita awal film Pak Guru yang sedang menanyakan hasil nilai ulangan sekaligus mengapsen siswanya. Dari penjelasan tersebut menunjukkan cerita awal pada film Dua Garis Biru berbeda dengan awal cerita pada novel Dua Garis Biru, melainkan film menggunakan credit title sebagai awal pengenalan unsur cerita atau hipogramnya. Perubahan bervariasi sangat jelas terlihat di bagian ini.

b. Dara mengerang pada Ibunya

Dalam novel Dua Garis Biru digambarkan Dara sebagai anak yang manja kepada Ibunya. Dara meminta diantar ke toilet ketika sedang menunggu antrian di rumah sakit. Berbeda dengan adegan dalam film Dua Garis Biru, Dara justru sedang duduk bersebelahan dengan Ibunya sambil membaca buku dan tidak menceritakan adegan Dara ingin ke toilet.

(Data 11)

Belum lama duduk, Dara mengerang.

"Ma, aku mau pipis." Dara memegang lengan Ibunya, terdengar seperti sedang merajuk.

"Tahan dulu. Sebentar lagi kan giliran kita." Wanita itu menyentuh tangan Dara.

"Udah nggak tahan, ma," jawab Dara manja. 
"Yaudah, ayo mama anterin". (Dua Garis Biru, 2019:163)

Berdasarkan kutipan di atas, menunjukkan dalam novel diceritakan Dara yang sedang menunggu antrian di rumah sakit bersama keluarganya dan keluarga Bima. Belum lama duduk bersebelahan dengan Ibunya, Dara meminta diantar ke toilet sambil memegang lengan ibunya.

\section{Bentuk Ekranisasi Tokoh dari Novel Dua Garis Biru ke bentuk Film Dua Garis Biru Pengurangan/Penghilangan Tokoh}

a. Tokoh Om Ifan

Dalam novel Dua Garis Biru tokoh Om Ifan di tampilkan/diceritakan pada bab "Kuliah". Berdasarkan pengamatan penelitian tokoh Om Ifan merupakan tokoh yang dianggap penting karena mampu memengaruhi perubahan alur cerita. Namun, dalam film Dua Garis Biru tidak menampilkan tokoh Om Ifan.

(Data 12)

...Ibunya keluar dari rumah sembari mengulur sebuah kabel rol hitam. Ibu Bima berdehem, tanda ia akan nimbrung dalam pembicaraan.

"Om Ifan lagi cari pegawai di tokonya tuh, bagian administrasi," (Dua Garis Biru, 2019:83)

Kutipan di atas memaparkan dalam novel Dua Garis Biru di ceritakan tokoh Om Ifan yang sedang membutuhkan karyawan bagian adimistrasi di tokonya.

b. Tante Tita dan Rara

Dalam novel Dua Garis Biru tokoh Tante Tita dan Rara ditampilkan/diceritakan ketika Puput ingin berhenti mengikuti gymnastic. Tante Tita dan Rara merupakan keluarga yang dinginkan oleh Ibu Dara karena kompak dan mensuport hobi anak dengan keinginannya sendiri.

(Data 13)

"Gue nggak mau gymnastic lagi"

"Bukannya elo yang mau?" Dara mencoba membuat Puput bertanya pada dirinya sendiri.

Puput segera menggeleng kuat-kuat.

"Mama yang mau kan? Soalnya anak Tante Tita juga ikut gymnastic."

Dara ingat pernah beberapa kali mendengar Ibunya memuji Rara anak Tante Tita, temen Ibunya yang jago senam. Sudah dapat piala di usia lima tahun. (Dua Garis Biru, 2019:36)

Kutipan di atas memaparkan dalam novel Dua Garis Biru diceritakan tokoh Tante Tita yang selalu mensuport hobi yang di ikutinya anaknya. Sedangkan Ibu Dara menyuruh Puput untuk terus mengikuti gymnastic tetapi justru Puput lebih suka ke musik ukulele.

c. Aldi

Dalam novel Dua Garis Biru tokoh Aldi di tampilkan/diceritakan ketika Vini asik curhat ke Dara karena Aldi tidak membalas massage di IG-nya sehingga membuat Vini merasa kesal dan menceritakan semuanya kepada Dara. Namun, di dalam film tidak menampilkan tokoh Aldi.

(Data 14)

"Makanya gue kesel banget sama Aldi. Masa dia nggak bales message gue, tapi masih online di IG..."

"Pas gue tanya, dia cuma jawab 'hmmm'..." Vini melanjutkan (Dua Garis Biru, 2019:45)

Kutipan di atas memaparkan dalam novel Dua Garis Biru diceritakan tokoh Aldi yang berlaku cuek kepada Vini sehingga membuatnya kesal.

d. Mba Mila

Dalam novel Dua Garis Biru tokoh Mba Mila di tampilkan/diceritakan ketika Bima mencari tahu tempat aborsi kandungan kepada Emir dan Danang.

(Data 15)

"Mir...ingat Mba Mila nggak? Yang ngegugurin kandungannya dulu? Dimana ya tempat dia ngegugurin?"

"Oh iya tuh si Mila. Ngurutnya di Emak Naim". (Dua Garis Biru, 2019:64) 
Kutipan di atas memaparkan dalam novel Dua Garis Biru diceritakan tokoh Mba Mila yang pernah gugurin kandungannya di Emak Naim.

e. Dian

Dalam novel Dua Garis Biru tokoh Dian di tampilkan/diceritakan ketika Vini bertanya pada Dara dan Bima untuk menghadiri syukuran di ulang tahunnya.

(Data 16)

"Dar..Bim..,ntar ke rumah Dian nggak?

Bima lupa-lupa ingat. Kalau tidak salah syukuran ulang tahunnya yang ke 17.

"Dara nggak enak badan" saut Bima dan menggeleng cepat. (Dua Garis Biru, 2019:80)

Kutipan di atas dalam novel memaparkan tokoh Dian yang mengundang teman-temannya untuk datang ke acara syukuran di ulang tahunnya.

f. Rizki

Dalam novel Dua Garis Biru tokoh Rizki di tampilkan/diceritakan ketika Bima merasa pusing dan bingung dengan tuduhan-tuduhan Ibunya, karena lupa membawa motor ke rumah sepulang sekolah.

(Data 17)

"Kamu jual motormu ya?" Ibu Bima menawarkan pilihan jawaban.

"Atau kamu pakai narkoba, kayak si Rizki anaknya Bu Ani?"

"Anak kita pakai narkoba, Pak?! (Dua Garis Biru, 2019:53)

Kutipan di atas dalam novel Dua Garis Biru memaparkan tokoh Rizki yang pernah mengkonsumsi narkoba.

\section{Penambahan}

(Data 18)

a. Vini

Pada film Dua Garis Biru memunculkan tokoh-tokoh baru salah satunya yaitu Vini. Tokoh tersebut dapat kita jumpai pada bagian awal saat melewatinya di tengah-tengah Bima dan Dara saat sedang berebut ponselnya ketika hendak pulang. Namun, tokoh dan bagian tersebut tidak kita jumpai pada novel Dua Garis Biru.

(Data 19)

b. Eni

Pada film Dua Garis Biru memunculkan tokoh-tokoh baru salah satunya yaitu Vini. Tokoh tersebut dapat kita jumpai pada bagian tengah ketika Dara akan menerima lamaran dari Bima. Sementara Ibu Dara tergesa-gesa karena akan mengantar Puput berenang dan menyuruh Eni untuk membantu mencari ponselnya. Namun, tokoh dan bagian tersebut tidak kita jumpai pada novel Dua Garis Biru.

\section{Perubahan bervariasi tokoh}

Proses ekranisasi juga memungkinkan terjadinya variasi-variasi tertentu antara novel dan film. Salah satunya yaitu perubahan bervariasi tokoh, dimana karakter atau peran tokoh di dalam suatu novel mengalami perubahan saat difilmkan. Seperti dalam film Dua Garis Biru tokoh Bu Saodah berperan sebagai Ibu berdaster yang sedang mengobrol dengan lbu Bima di depan rumahnya. Sementara di dalam novel Dua Garis Biru Bu Saodah membeli gado-gado Bu Yuni, singkat cerita Bima di suruh ibunya untu mengantarkan pesanan dan kembalian ke rumah Bu Saodah.

\section{Implikasi Pembelajaran Sastra dalam Ekranisasi Novel Dua Garis Biru ke Film Dua Garis Biru}

Penelitian ini memiliki hubungan dengan materi ekranisasi atau alihwahana (novel ke film) yang ada pada kurikulum 2013. Materi ekranisasi atau alihwahana terdapat pada kelas XII semester 2 dengan kompetensi dasar yaitu 3.9 Menganalisis isi dan kebahasaan novel, dan 4.9 Merancang novel atau novelet dengan memerhatian isi dan kebahasaan baik secara lisan maupun tulis. 
Dengan ditemukan beberapa unsur-unsur instrinsik pada novel Dua Garis Biru dapat diimplikasikan dalam pembelajaran sastra khususnya pembelajaran ekranisasi novel ke film yang lebih spesifik ke alur dan tokoh/penokohan. Dalam novel terdapat beberapa unsur instrinsik, diantaranya tema, tokoh, penokohan, alur, latar, dan amanat.

Selain itu penelitian ini juga dapat menambah wawasan dan keterampilan berbahasa peserta didik seperti berbicara yang dapat diimpikasikan untuk pembelajaran novel, yaitu mengangapi cara pembacaan novel atau menceritakan kembali isi novel. Membaca dapat diimplikasian untuk mengembangkan teori dalam pembelajaran sastra khususnya novel. Dengan adanya pemanfaatan unsur-unsur instrinsik dalam novel maka dalam membaca novel dapat menyebutkan unsur-unsur instrinsik yang terdapat dalam novel. Menulis dapat diimplikasikan untuk pengembangan stilistika dalam pembelajaran novel, sehingga pada pembelajaran novel, siswa mampu mengungkapkan pikiran dan perasaan melalui kagiatan menulis ciri-ciri dan unsur-unsur instrinsik novel. Selain itu penelitian ini dapat diimplikasikan untuk digunakan sebagai bahan ajar dalam mengapresiasi novel, guru dapat menjelaskan unsur-unsur instrinsik novel agar siswa dapat memahami.

\section{SIMPULAN}

Hasil penelitian mengenai ekranisasi novel Dua Garis Biru karya Lucia Priandarini ke bentuk film Dua Garis Biru karya Gina S. Noer, disimpulkan bahwa ekranisasi dari novel ke film sebagai berikut. Dalam novel Dua Garis Biru terdapat bentuk ekraniasai penambahan bagian cerita novel Dua Garis Biru ke dalam film Dua Garis Biru terjadi perbedaan alur pembuka. Pada novel menceritakan tentang Bima yang selalu mendapatkan nilai jelek karena kemalasannya dan tidak mementingkan untuk masa depan. Sementara dalam film Pak Yudi langsung mengapsen siswa dengan menyuruh menyebutkan nilai ulangannya. Bentuk ekranisasi pengurangan tokoh novel Dua Garis Biru ke dalam film Dua Garis Biru menyebabkan penghilangan beberapa tokoh, seperti Om Ifan, Tante Tita dan Rara, Aldi, Mba Mila, Dian, Rizki. Mengurangi tokoh berarti juga mengurangi beberapa peristiwa atau konflik yang terjadi dalam novel yang berkaitan dengan tokoh-tokoh tersebut. Bentuk ekranisasi perubahan berbagai variasi pada alur bagian cerita novel Dua Garis Biru Ketika masuk pada adegan utama, antara novel dan film memiliki perbedaan yang sangat jelas, novel Dua Garis Biru menggunakan alur maju-mundur (campuran), sedangkan dalam film Dua Garis Biru menggunakan alur maju. Sedangkan dalam film adegan diawali dengan creadit title yaitu adegan hasil modifikasi yang dilakukan pada alur film, karena tidak ditemukannya adegan ini pada novel yang berfungsi sebagai hipogram atau unsur ceritanya. Implikasi hasil penelitian dalam novel Dua Garis Biru karya Lucia Priandarini ke bentuk film Dua Garis Biru karya Gina S. Noer dapat digunakan dalam pembelajaran bahasa Indonesia di SMA kelas XII pada materi dengan kompetensi dasar 3.9 Menganalisis isi dan kebahasaan novel.

\section{REKOMENDASI}

Penelitian tentang ekranisasi novel ke dalam film pada novel Dua Garis Biru ini hanya sebagian kecil dari penelitian sastra. Penelitian selanjutnya dapat mengkaji dengan pendekatan yang lainnya. Perlu dilakukan penelitian lebih lanjut mengenai ekranisasi novel ke bentuk film dan implementasinya terhadap pembelajaran. Saat ini, pengaruh globalisasi berdampak besar terhadap pergaulan anak remaja. Untuk itu, peran Orangtua sangat besar dalam mengawasi dan mendidik anaknya. Agar tidak terpengaruh dengan hal negatif yang merugikan diri sendiri maupun orang lain.

\section{UCAPAN TERIMAKASIH}

Terima kasih kepada Fakultas Keguruan dan IImu Pendidikan Universitas Galuh Ciamis, yang telah membantu penulis dalam publikasi artikel ini dan terima kasih juga untuk pihak-pihak yang telah membantu dalam pelaksanaan penelitian. 


\section{DAFTAR PUSTAKA}

Aminuddin. (2013). Pengantar Apresiasi Karya Sastra. Bandung: Sinar Baru Algensindo.

Damono, Sapardi Djoko. (2018). Alihwahana. Jakarta: PT. Gramedia Pustaka Utama.

Boggs, Joseph M. (1992). Cara Menilai Sebuah Film (diterjemahkan oleh Asrul Sani). Jakarta: Yayasan Citra.

Eneste, Pamusuk. (1991). Novel dan Film. Flores. Nusa Indah.

Kartika, Pheni Cahya. (2016). Rasionalisasi Perspektif Film Layar Lebar Beradaptasi Karya Sastra. Jurnal Bahasa dan Sastra Indonesia serta Pengajarannya. Volume 2, Nomor 2.

Priandarini, Lucia. (2019). Novel Dua Garis Biru. Jakarta: PT Gramedia Pustaka Utama.

Nurgiyantoro, Burhan. (2015). Teori Pengkajian Fiksi. Yogyakarta: Gajah Mada University Press.

Nurgiyantoro, Burhan. (2002). Teori Pengkajian Fiksi. Yogyakarta: Gadjah Mada. University Press.

Ratna, Nyoman Kutha. (2015). Teori, Metode, dan Teknik Penelitian Sastra. Yogyakarta: Pustaka Pelajar.

Rokhmansyah, Alfian. (2014).Studi dan Pengkajian Sastra. Yogyakarta: Graha Ilmu.

Sugiyono. (2015). Metode Penelitian Kuantitatif, Kualitatif dan R\&D. Bandung: Alfabeta. 